\title{
The Relationship between Self-esteem, Personality Type and Reading Comprehension of Iranian EFL Students
}

\author{
Mohammad Sadeq Bagheri \\ Department of Foreign Languages, Shiraz Branch, Islamic Azad University, Shiraz, Iran \\ Email: bagheries@gmail.com \\ Mehrnaz Faghih \\ Department of Foreign Languages, Shiraz Branch, Islamic Azad University, Shiraz, Iran \\ Email:mehrnazf66@gmail.com
}

\begin{abstract}
This study aimed at investigating the relationship between self-esteem, personality type and reading comprehension of Iranian EFL students. Data of this study were collected by administering a questionnaire of self-esteem including three sections: global self-esteem, situational self-esteem and task self-esteem, questionnaire of personality type measuring extroversion and TOEFL reading comprehension test that were prepared by the researcher. The instruments were administered to a random sample from English Institutes. The sample consisted of 55 students (13 males and 42 females). Pearson Coefficient-Moment Product Correlation was used to determine the relationship between variables. Results of the study revealed that there was a positive relationship between overall self-esteem and reading comprehension, and overall self-esteem and personality type, in general. Likewise, positive relationships between situational and task self-esteem with reading comprehension were shown but there wasn't a significant relationship between global self-esteem and reading comprehension. Also the relationship between personality type and reading comprehension was insignificant.
\end{abstract}

Index Terms — self-esteem, personality type, reading comprehension, relationship

\section{INTRODUCTION}

Nowadays, learning English has become a necessity all over the world. English is the most common language in the world. Learning English requires mastering of the four language skills listening, speaking, reading and writing. Reading is the most important academic skill. In spite of this crucial role of reading, many students still have problems concerning reading. This seems true even if the learners have a considerable amount of linguistic knowledge. Therefore, it can be suggested that there are some non-linguistic factors in the process of reading comprehension. Anders (2002) claims that language learning is affected by both domains which are the mental and emotional sides of human behavior.

Two important factors that affect the process of reading and consequently the process of comprehension are the reader variable and the text variable. Reader variables are the strategies used by readers, their background knowledge, motivation, personality, self-esteem and sex. In recent years, the importance of these factors has been of interest in the field of language learning because of their high effects on learning a foreign or a second language (Anders, 2002). One of the important reader's variable is personality.

In modern language teaching today, relating individually with the students on academic basis and trying to learn more about the student profile provides further advantages for the language learner and the teacher to meet the program goals and objectives. Here, the personality of the student appears to be in the core of the issue.

Much research regarding reading has been concerned with the attempt to identify individual differences (ID) as source of large variances typically obtained in measures of reading comprehension. The major IDs have tended to be cognitive like intelligence or achievement like GPA. The role of personality has been much less a concern of researchers (Farely, 1970). Schmeck (1988)makes it clear that is important and useful to identify "educationally relevant personal attributes," but researchers seem to be doing less and less in this area. For example, the yearly IRA Annual Summary of Investigations Relating to Reading annually includes up to 800 studies, but over the past five years has listed fewer than a dozen studies on the relationship of personal variables and reading comprehension (Weintraub, 1992).

People differ from one another depending on their personalities. Wilz (2000) expresses the need for personality type understanding on the part of the teacher: "An awareness of student personality types allows teachers to have a better understanding of the classroom dynamics and to be better able to determine what kinds of classroom activities and strategies would be most effective with a majority of students in the class" (p, 29). Experts think that an understanding of personality types can help teachers explain why students approach tasks differently. Some of them succeed while 
some fail (Oxford\&Ehrman, 1990; Wilz 2000). In research, extroversion appears to receive great attention by scholars to study among other traits in personality (Davies, 2004).

Many second language teachers somehow feel that a student with an outgoing personality is more likely to be successful as a second language learner than his less sociable classmate. Coleman (1960) found that student's personality is among variables that is related to achievement.

Self-esteem is an extremely popular construct within the field of psychology and has been related to virtually every other psychological concept or domain, including personality (Asadi, 2010). Success is not measured by how much one gains but of how satisfied one is with one's work (Daniel \& King, 1995; Grandin, 2002). Hence, a person should put a high value for his performance and be confident of his achievement because those judgments he makes are the drive for mastering proficiency (Stout, 2001). Moreover, Branden (1985) indicates that the biggest barrier to success is not lack of ability or talent but it is lack of self-esteem. Researchers found self-esteem affects achievement. Brown (2000) maintains that "no successful activity can occur without some degree of self-esteem"(p.145).

Demo and Parker (1987) believe that in real situations both self-esteem and language learning are interacting variables, in the sense that language learning can affect the degree of self-esteem and vice versa; that is to say, by strengthening one, the other factor will be strengthened.

Self-esteem has two aspects: self confidence which is the sense of efficacy and self respect which is the sense of worthiness (Branden,2001). So, self-esteem reflects the student's feelings about one's self. Stevick (1990) states that "learning is affected by how students feel about themselves" (p.25). Traditionally, self-esteem is frequently used in related literature synonymously with the terms "self-concept","self-competence" and "self-efficacy" although they are different (Pajares \& Johnson, 1993; Daniel \& King, 1995). To differentiate between the two concepts, McCarthy \& Schmeck (n.d.) assume that "self-concept is the most significant cognitive structure organizing an individual's experience, while self-esteem is the most influential affective evaluator of this experience" On the other hand, Branden (2001) views self-efficacy as a part of self-esteem. Rosenberg (1979) believed self-concept was slow forming, with many changes taking place in middle childhood and adolescence, and the self-concept is never static but continues to change throughout one's life.

Most studies (Branden, 1988; Apter, 1998; Murk, 1999; Branden, 1999; Coopersmith, as cited in Timothy et al., 2001) consider self-esteem as the personal judgment, opinion and the internal attitude of one's self. If this judgment is positive, it will lead learners to success. If it is negative, it leads to troubles and low academic achievement. In other words, students who feel good about themselves are the ones who most likely to do better. Likewise, important people in one's life such as parents, friends or teachers form ones' view about the self. A person consciously or unconsciously adopts others' judgments and deals with them as reality (Roberts, 2003). In brief, the internal picture of oneself is drawn by judgments made of the person him/herself or by people around him. Others could build or damage self-esteem by their positive or negative views.

Various aspects of learning language skills are affected by self-esteem. A number of studies (Heyde, 1979; Hassan, 1992; Truitt, 1995; Shumin, 1997; Timothy et al., 2001) concluded that self-esteem is strongly correlated with oral communicative proficiency and low self-esteem students cannot express themselves with confidence. Similar results yielded in the area of writing (Frankburger, 1991; Grodnick, 1996; Cronwell \& Mackay, 1999; Hassan, 2001) indicated that self-esteem can affect writing success. In addition, other studies (Hutchison, 1972; Sweet, 1977; Richardson, 2003) indicated that self-esteem can affect reading. Throughout the above mentioned studies, it is found that most of those studies focus on the relationship between self-esteem and reading more than its relationship to personality. Little attention has been paid to the association of self-esteem, personality and reading comprehension. Consequently, the present study tries to investigate the relationship between self-esteem, personality and reading comprehension among Iranian EFL students.

Due to the aforementioned discussion, these null hypotheses are posed:

1) There is no significant relationship between overall self-esteem and reading comprehension.

2) There is no significant relationship between global self-esteem and reading comprehension.

3) There is no significant relationship between situational self-esteem and reading comprehension.

4) There is no significant relationship between task self-esteem and reading comprehension.

5) There is no significant relationship between extroversion and reading comprehension.

6) There is no significant relationship between self-esteem and extroversion.

\section{LITERATURE REVIEW}

In this section studies related to self-esteem, personality and language skills are included. Reza Hajimohammadi (2011) explored the impact of self correction on extrovert and introvert students in EFL writing process.120 preintermediate students were chosen through Nelson English Language Test and EPQ. They were categorized in two groups extroverts and introverts and the expository topics were administered to them in a 5 week period. The study revealed that personality type had no significant effect on writing.

Achmat Qomarudin (2010) investigated the relationship between extroversion and English writing skill in Indonesia.30 students studying in $8^{\text {th }}$ semester of English were selected randomly. The researcher collected data through 
Eysenck Personality Inventory (EPI) and transcript scores of students. The results showed that there was a positive relation between extroversion and writing skill.

Ismail Erton (2010) investigated the relationship between personality type and success in foreign language achievement. Maudsley's 'Personality' and Barsch's 'Learning Styles' inventories were distributed to freshman students studying at the Faculty of Engineering, Science, Economics, Fine Arts, and Humanities \& Letters in Bilkent University, who received the English 101 course in their first year at the university. The findings showed that there is not a statistically strong, but a low relationship between the personality traits of the learners and success in language achievement.

Gheedjz (2010) investigated the relationship between personality type, test anxiety, self-esteem and academic achievement, which was measured by the students GPA. The study was conducted at a university in Indiana using undergraduate students. He administered a scale from the MBTI to determine personality types (introvert or extrovert), also Rosenberg's 10 - item scale for self-esteem, and Spielberger's test anxiety inventory. The hypothesis was that extraverts who have a higher self-esteem, and low test anxiety would have better success with academic achievement than those who are introverts with low self-esteem and high test anxiety. It was found in this study that there was no significant relationship between personality type, test anxiety, self-esteem and academic achievement.

Majid Hayati and Mohsen Ostadian (2008) investigated relationship between listening and self-esteem.60 intermediate students were selected through proficiency test. Coopersmith test and TOEFL listening comprehension were administered to them. The results showed that their listening comprehension was significantly affected by selfesteem.

Fahimeh Mavedat (2006) explored students' writing and personality type of the students.86 male and female graduate and undergraduate EFL students were given the Meyers-briggs type indicator. The average of students' scores on writing as well as final and midterm served as an index of writing. Analysis of the data showed that there is no significant relationship between extroversion and writing.

Ameerah Ali Moqbel (2006) investigated the relation between self-esteem and writing. A questionnaire of selfesteem including 3 sections and English writing achievement test were administered to 81 students. Pearson coefficient correlation was used to show correlation. The results indicated that there's a positive relation between self-esteem and writing in general.

Toeko Oya (2004) explored the relation between personality and anxiety characteristic of Japanese students and their oral performance in English. Participants were 73 native speakers of Japanese who were studying English. Maudsley personality inventory, Spielberg state anxiety inventory and story retelling task were administered to the students. Results showed students who were more extraverted produced better performance.

\section{METHOD}

\section{A. Participants}

The participants were randomly selected from male and female students enrolled in English institutes. All students were adults. Participants consisted of 55 students studying in advance levels. Advanced students were selected so that they could answer TOEFL reading comprehension tests.

\section{B. Materials}

To investigate the relationship between self-esteem and personality on reading comprehension test three instruments are used. The first one is questionnaire of self-esteem (QSE) by Hyde (1979) and the second one is short form revised Eysenek personality questionnaire (EPQ-S) by Eysenek (1985) and the third one is TOEFL reading comprehension test. Reliability and validity of them were checked. Due to the fact that TOEFL is a standard test its reliability and validity are assumed to be satisfactory. Since only reading comprehension of TOEFL was administered to the students, reliability and validity of the test were checked. Cronbach alpha of .890 was obtained. Since it measured one construct, it was a valid test. The reliability and validity of QSE were checked. To determine the reliability of the QSE, the Spilthalf Method was used. The questionnaire was divided into odd and even numbers, thirty items each. Then the Correlation between the two parts was computed using Spearman-Brown Formula. Results are shown in the table 1.

TABLE 1.

THE CORRELATION BETWEEN THE TWO HALVES (ODD \& EVEN) OF THE QSE

\begin{tabular}{|l|l|l|l|}
\hline items & Std.Deviation & mean & Spearman's correlation \\
\hline Odd & .594 & 3.97 & $.900^{* *}$ \\
\hline Even & .451 & 3.69 & \\
\hline
\end{tabular}

The correlation between the two halves of the QSE was.900, it was statistically significant at the level of 0.01. Based on these results, the QSE is reliable. Intrinsic validity was obtained by applying the following formula: Intrinsic validity $=\sqrt{ }$ Reliability item Intrinsic validity of the QSE $=\sqrt{ } .900=.948$

The intrinsic validity was .948. Based on this result, the QSE is a valid tool. The reliability and validity of EPQ-S were checked. In this study Cronbach alpha of .703 was calculated. This result showed that it has internal consistency. 
To ensure the content validity of the test, the committee members' advice was sought. Each strongly confirmed the appropriateness of the test.

\section{Procedure}

Data collection was done in two sessions at Baran and SILDI Institutes in February 2012. First, TOEFL reading comprehension test was administered to the participants. The students were given 55 minutes to answer TOEFL reading comprehension test. The following session, they were asked to answer QSE in 25 minutes and after a short break EPQ-S was administered to them. They were asked to return them in 5 minutes. The researcher himself administered the questionnaires and the test. He explained to the respondents the purpose and the procedures of the questionnaires and the test.

The participants were assured that their responses would be kept confidential and would not affect their marks. The researcher also made the students aware of the fact that that their participation would help all Iranian learners to learn English more efficiently. In short, all required information was given to the participants before administering the instruments, information like how to answer the questions and the test.

Data collected from the questionnaires were analyzed using the Statistical Package for Social Science (SPSS). To answer research questions Pearson Product Moment Correlation was used to identify the strength and the direction of the relationship between variables.

\section{RESUltS AND DisCUSSIONS}

\section{A. Hypothesis 1}

To investigate the first hypothesis, coefficient of correlation between overall self-esteem and reading comprehension was calculated and they were shown in Table 2.

TABLE 2

CORRELATIONS BETWEEN OVERALL SELF-ESTEEM AND READING

\begin{tabular}{|ll|l|}
\hline & & reading \\
\hline overall & Pearson Correlation & $.337(* *)$ \\
& Sig. (2-tailed) & .012 \\
& $\mathrm{~N}$ & 55 \\
\hline
\end{tabular}

* Correlation is significant at the 0.01 level (2-tailed).

The correlation between overall self-esteem and reading comprehension was $r=.337$. The correlation between the two variables was significant at the level of 0.01 .

This level of Pearson Coefficient Correlation indicated that the correlation was positive. This means that there was an association between the dependent and independent variables. When student's self-esteem increases his/her achievement in TOEFL reading comprehension increases and vice versa. Based on this result, the first null sub-hypothesis was rejected.

\section{B. Hypothesis 2}

To investigate the second hypothesis, coefficient of correlation between global self-esteem and reading comprehension was calculated and they were shown in Table 3.

TABLE 3

\begin{tabular}{|c|c|c|}
\hline & & reading \\
\hline global & $\begin{array}{l}\text { Pearson Correlation } \\
\text { Sig. (2-tailed) } \\
\mathrm{N}\end{array}$ & $\begin{array}{l}.204 \\
.136 \\
55\end{array}$ \\
\hline
\end{tabular}

The correlation between global self-esteem and TOEFL reading comprehension test, as shown in Table 3 was $r$ $=.204$. This level of Pearson Coefficient of Correlation indicated that there was no relationship between the two variables. This means that it is not necessary that; when student's global self-esteem increases his/her achievement in English reading comprehension test may increase and vice versa because the correlation between the two variables was insignificant. Based on this result, the second null hypothesis was accepted.

\section{Hypothesis 3}

To investigate the second hypothesis, coefficient of correlation between situational self-esteem and reading comprehension was calculated and they were shown in Table 4. 
TABLE 4

CORRELATIONS BETWEEN SITUATIONAL SELF-ESTEEM AND READING

\begin{tabular}{|ll|l|}
\hline & & reading \\
\hline situational & Pearson Correlation & $.455(* *)$ \\
& Sig. (2-tailed) & .000 \\
& $\mathrm{~N}$ & 55 \\
\hline
\end{tabular}

** Correlation is significant at the 0.01 level (2-tailed).

The correlation between situational self-esteem and TOEFL reading comprehension test, as shown in Table 4 was $r$ $=.455$. This level of Pearson Coefficient of Correlation indicated that the correlation was significant at the 0.01 level. This means that there was a relationship between the two variables. When student's situational self-esteem increases, his/her achievement in reading comprehension test increases and vice versa. In light of this result, the third null hypothesis was rejected.

\section{Hypothesis 4}

To investigate the fourth hypothesis, coefficient of correlation between task self-esteem and reading comprehension was calculated and they were shown in Table 5.

TABLE 5

CORRELATIONS BETWEEN TASK SELF-ESTEEM AND READING

\begin{tabular}{|ll|l|}
\hline & & reading \\
\hline task & Pearson Correlation & $.319\left({ }^{*}\right)$ \\
& Sig. (2-tailed) & .018 \\
& $\mathrm{~N}$ & 55 \\
\hline
\end{tabular}

* Correlation is significant at the 0.05 level (2-tailed).

The correlation between task self-esteem and TOEFL reading comprehension test, as shown in Table 4 was $r=.319$. This level of Pearson Coefficient of Correlation indicated that the correlation was significant at the 0.01 level. This means that there was a relationship between the two variables.

\section{E. Hypothesis 5}

To investigate the fifth hypothesis, coefficient of correlation between personality and reading comprehension was calculated and they were shown in Table 6.

TABLE 6

CORRELATIONS BETWEEN PERSONALITY AND READING

\begin{tabular}{|ll|l|}
\hline & & reading \\
\hline personality & Pearson Correlation & .214 \\
& Sig. (2-tailed) & .117 \\
& $\mathrm{~N}$ & 55 \\
\hline
\end{tabular}

The correlation between extroversion and TOEFL reading comprehension test, as shown in Table 4.13 was $r=.214$. This level of Pearson Coefficient of Correlation indicated that there was no relationship between the two variables. This means that it is not necessary that; when a student is extrovert, his/her achievement in English reading comprehension test may increase and vice versa because the correlation between the two variables was insignificant. Based on this result, the fifth null hypothesis was accepted.

\section{F. Hypothesis 6}

To investigate the sixth hypothesis, coefficient of correlation between personality and self-esteem was calculated and they were shown in Table 7.

TABLE 7

CORRELATIONS BETWEEN PERSONALITY AND SELF-ESTEEM

\begin{tabular}{|ll|l|}
\hline & & overall \\
\hline personality & Pearson Correlation & $.352(* *)$ \\
& Sig. (2-tailed) & .008 \\
& $\mathrm{~N}$ & 55 \\
\hline
\end{tabular}

* Correlation is significant at the 0.01 level (2-tailed

The correlation between self-esteem and extroversion, as shown in Table 4.14 was $r=.352$. This level of Pearson Coefficient of Correlation indicated that the correlation was significant at the 0.01 level. This means that there was a 
relationship between the two variables. When a student is extrovert, his self-esteem increases and when he is introvert his self-esteem decreases. In light of this result, the sixth null hypothesis was rejected.

Extroversion had no significant relationship with reading comprehension. It is in agreement with findings like those of Naiman et al (1978), Suter (1976) and Busch (1982) who state that there is no significant relation between extroversion/ introversion measure and performance on listening comprehension, pronunciation, reading and grammar since the introverts tended to have higher scores in these tasks. Others, on the other hand, claim that "extroverts showed to be better in oral communicative speech, and have lower levels of anxiety thanks to their good physiological equipment to resist stress". (see Ellis 2004, pp. 541-42).

The above mentioned results of the present study revealed that self-esteem is positively correlated with reading comprehension and extraversion. This means that when student's self-esteem increases his/her achievement in reading comprehension increases and conversely when student's self-esteem decreases his/her achievement in reading comprehension decreases. Furthermore, when a student is extrovert his self-esteem increases and when he is introvert his self-esteem decreases. This result is consistent with studies reported by Swartz (1972); Gardner (1972); Hutchinson (1972) and Sweet\& Burbach (1972) who found that self-esteem strongly impacts reading comprehension. The results are also in agreement with studies reported by Yi Xue Za (2006) who found that there is a positive relationship between self-esteem and extroversion. But it is in contradiction with findings of Gheedjz (2010) who found no relationship between self-esteem and extroversion. The finding of the present research about an insignificant relationship between personality and reading comprehension is in agreement with the findings of Hosseini \& Kafipour (2011) and Farely \& Truog (1971). On the other hand the results are in contradiction with studies by Vivan (2006) and Riding \& Cowley (2011) who found a significant relationship between personality and reading.

\section{CONCLUSION}

Self-esteem is found to be an important affective factor. It plays a considerable role in reading comprehension. Selfesteem should be taken into consideration as a serious issue when planning English lessons. EFL teachers should take into consideration the individual differences among students and the different environments they come from. EFL students who have low self-esteem should be trained to overcome their negative feelings about themselves and look positively at their EFL learning capabilities. EFL teachers should accept students' mistakes as a natural part of learning and encourage trying and risk-taking in English learning. Using specific instruments that measure specific language learning areas leads to more accurate findings.

\section{APPEndix A: QuestionnAIRE OF SELF-ESTEEM}

SECTION (A)

Global Self-esteEm

\begin{tabular}{|l|l|l|l|l|l|l|}
\hline $\begin{array}{l}\text { Item } \\
\text { No. }\end{array}$ & statement & $\begin{array}{l}\text { Strongly } \\
\text { agree }\end{array}$ & agree & undecided & disagree & $\begin{array}{l}\text { Strongly } \\
\text { disagree }\end{array}$ \\
\hline 1 & I give up when I face any difficulty. & & & & \\
\hline 2 & It is difficult for me to do what I want without the help of others. & & & & \\
\hline 3 & I avoid the leadership role in my life. & & & & & \\
\hline 4 & I avoid voluntary tasks. & & & & & \\
\hline 5 & I blame myself a lot when I make a mistake. & & & & \\
\hline 6 & $\begin{array}{l}\text { When I differ with others, I cannot insist on my opinion even } \\
\text { though I believe it is right. }\end{array}$ & & & & \\
\hline 7 & $\begin{array}{l}\text { I hesitate to participate in a discussion, even though I know a lot } \\
\text { about the discussed topic. }\end{array}$ & & & & \\
\hline 8 & $\begin{array}{l}\text { I often comply with others' opinions even though I am not } \\
\text { convinced. }\end{array}$ & & & & & \\
\hline 9 & I believe others' reactions towards me are criticism. & & & \\
\hline 10 & I avoid any situations where others observe me. & & & & \\
\hline 11 & I speak confidently when I am sure of what I am saying. & & & & \\
\hline 12 & I feel unsatisfied with my abilities no matter what efforts I exert. & & & & \\
\hline 13 & I feel that people often consider what I say as unimportant. & & & & \\
\hline 14 & I believe I have not achieved any beneficial thing in my life. & & & & & \\
\hline 15 & New situations in my life make me feel unsafe. & & & \\
\hline 16 & I give up my rights easily with my friends. & & & \\
\hline 17 & $\begin{array}{l}\text { I don't like to be the first to answer even though I know the right } \\
\text { answer. }\end{array}$ & & & & & \\
\hline 18 & Other's criticism makes me withdraw from meeting them. & & & & \\
\hline 19 & $\begin{array}{l}\text { When I compare myself to my peers,I feel they are better than } \\
\text { me. }\end{array}$ & & & & & \\
\hline 20 & I can help my friends when we are assigned a group work. & & & & \\
\hline
\end{tabular}




\begin{tabular}{|c|c|c|c|c|c|c|}
\hline $\begin{array}{l}\text { Item } \\
\text { No. }\end{array}$ & statement & $\begin{array}{l}\text { Strongly } \\
\text { agree }\end{array}$ & agree & undecided & disagree & $\begin{array}{l}\text { Strongly } \\
\text { disagree }\end{array}$ \\
\hline 1 & I cannot learn English. & & & & & \\
\hline 2 & I feel my ideas in English are meaningless. & & & & & \\
\hline 3 & I don't dare to say my thoughts in English. & & & & & \\
\hline 4 & I feel uneasy in English tasks. & & & & & \\
\hline 5 & I understand a lot of things during the English lessons. & & & & & \\
\hline 6 & I don't feel shy of reading aloud during English classes. & & & & & \\
\hline 7 & I can speak English in front of my classmates. & & & & & \\
\hline 8 & $\begin{array}{l}\text { I dislike competing in English lessons because I fear } \\
\text { failure. }\end{array}$ & & & & & \\
\hline 9 & I feel embarrassed when I discuss anything in English . & & & & & \\
\hline 10 & $\begin{array}{l}\text { I feel embarrassed when my English teacher asks me to } \\
\text { repeat my answer. }\end{array}$ & & & & & \\
\hline 11 & I feel I'm ineffective in English tasks. & & & & & \\
\hline 12 & I like group discussions in English classes & & & & & \\
\hline 13 & $\begin{array}{l}\text { I can speak English with my teacher only in private, but } \\
\text { not in front of others in the class. }\end{array}$ & & & & & \\
\hline 14 & $\begin{array}{l}\text { I don't work hard on my English tasks because I doubt } \\
\text { that I will do them successfully. }\end{array}$ & & & & & \\
\hline 15 & $\begin{array}{l}\text { I feel unconfident that I did the right thing in English } \\
\text { takes unless others tell me so. }\end{array}$ & & & & & \\
\hline 16 & I make mistakes in English without being shy. & & & & & \\
\hline 17 & I don't feel nervous on oral tests in English. & & & & & \\
\hline 18 & $\begin{array}{l}\text { My participation in the English class adds nothing to } \\
\text { the class. }\end{array}$ & & & & & \\
\hline 19 & $\begin{array}{l}\text { I believe my abilities in English are the worst in the } \\
\text { class. }\end{array}$ & & & & & \\
\hline 20 & $\begin{array}{l}\text { I don't feel confused when it's my turn to answer in } \\
\text { English. }\end{array}$ & & & & & \\
\hline
\end{tabular}

SECTION (C)

TASK SELF-ESTEEM

\begin{tabular}{|c|c|c|c|c|c|c|}
\hline $\begin{array}{l}\text { Item } \\
\text { No. }\end{array}$ & statement & $\begin{array}{l}\text { Strongly } \\
\text { agree }\end{array}$ & agree & undecided & disagree & $\begin{array}{l}\text { Strongly } \\
\text { disagree }\end{array}$ \\
\hline 1 & I feel confident when taking reading tests. & & & & & \\
\hline 2 & $\begin{array}{l}\text { I feel worried when the reading tests are out } \\
\text { of a book }\end{array}$ & & & & & \\
\hline 3 & I don't care where the reading tests are from. & & & & & \\
\hline 4 & I love to read. & & & & & \\
\hline 5 & I think reading is a waste of time. & & & & & \\
\hline 6 & I think reading is boring. & & & & & \\
\hline 7 & It takes a long time to read. & & & & & \\
\hline 8 & $\begin{array}{l}\text { You like to broaden your interest through } \\
\text { reading }\end{array}$ & & & & & \\
\hline 9 & I read a lot. & & & & & \\
\hline 10 & $\begin{array}{l}\text { I like to improve vocabulary through } \\
\text { reading. }\end{array}$ & & & & & \\
\hline 11 & I hate reading. & & & & & \\
\hline 12 & $\begin{array}{l}\text { I think my reading comprehension is not as } \\
\text { good as my classmates. }\end{array}$ & & & & & \\
\hline 13 & $\begin{array}{l}\text { I get poor grades in reading comprehension } \\
\text { tests. }\end{array}$ & & & & & \\
\hline 14 & $\begin{array}{l}\text { I feel worried when reading tests are full of } \\
\text { unknown words. }\end{array}$ & & & & & \\
\hline 15 & $\begin{array}{l}\text { I prefer seen passages rather than unseen } \\
\text { passages. }\end{array}$ & & & & & \\
\hline 16 & $\begin{array}{l}\text { The last part I answer is reading } \\
\text { comprehension. }\end{array}$ & & & & & \\
\hline 17 & $\begin{array}{l}\text { I'd rather someone tell me information so I } \\
\text { won't have to read to get it. }\end{array}$ & & & & & \\
\hline 18 & I cannot comprehend readings easily. & & & & & \\
\hline 19 & I'm not satisfied with my reading ability. & & & & & \\
\hline 20 & $\begin{array}{l}\text { If the teacher asks us to summarize a } \\
\text { reading, I don't like to be the first one. }\end{array}$ & & & & & \\
\hline
\end{tabular}

APPENDIX B: QuestionNAIRE OF PERSONALITY 


\begin{tabular}{|c|c|c|c|}
\hline $\begin{array}{l}\text { Item } \\
\text { No. }\end{array}$ & statement & Yes & No \\
\hline 1 & Are you a talkative person? & & \\
\hline 2 & Are you rather lively? & & \\
\hline 3 & Do you enjoy meeting new people? & & \\
\hline 4 & $\begin{array}{l}\text { Can you usually let yourself go and enjoy } \\
\text { yourself at a lively party? }\end{array}$ & & \\
\hline 5 & $\begin{array}{l}\text { Do you usually take the initiative in making } \\
\text { new friends? }\end{array}$ & & \\
\hline 6 & $\begin{array}{l}\text { Can you easily get some life into a rather } \\
\text { dull party? }\end{array}$ & & \\
\hline 7 & $\begin{array}{l}\text { Do you tend to keep in background on social } \\
\text { occasions? }\end{array}$ & & \\
\hline 8 & Do you like mixing with people? & & \\
\hline 9 & $\begin{array}{l}\text { Do you like plenty of bustle and excitement } \\
\text { around you? }\end{array}$ & & \\
\hline 10 & $\begin{array}{l}\text { Are you mostly quiet when you are with } \\
\text { other people? }\end{array}$ & & \\
\hline 11 & $\begin{array}{l}\text { Do other people think of you as being very } \\
\text { lively? }\end{array}$ & & \\
\hline 12 & Can you get a party going? & & \\
\hline
\end{tabular}

\section{REFERENCES}

[1] Andres, V. (2002). The influence of affective variables on ESL/EFL learning and teaching [Electronic version]. The Journal of the Imagination in Language Learning and Teaching, 17, 1-5.

[2] Apter, T. (1998). The Confident Child. New York: Bantam Books.

[3] Asadi, A. (2010). Prevalence of anxiety and its relationship with self-esteem among Zabol University students, Iran. Educational Research, 5, 140-144.

[4] Branden, N. (1985). Honoring the Self; Self-esteem and Personal Transformation. New York: Bantam Books.

[5] Branden, N. (1999). The Art of Living Consciously. New York: Bantam Books.

[6] Branden, N. (2001). The psychology of self-esteem (32nd ed.). New York: Jossey-Bass, Inc

[7] Brown, H.D. (2000). Principles of language learning and teaching (4th ed.). San Francisco: Addison Wesley Longman, Inc.

[8] Busch, D. (1982). Introversion-extraversion and the EFL proficiency of Japanese students. Language Learning, 32 (1), $109-132$.

[9] Cronwell, S., \& Mackay, T. (1999). Measuring writing apprehension in Japan. Paper presented at the annual meeting of The Japan Association of Language Teaching. (ERIC Document Reproduction Service No. ED433712)

[10] Daniel, L., \& King, D. (1995). Relationships among various dimensions of self-esteem and academic achievement in elementary students. (ERIC Document Reproductio Service No. ED 403008)

[11] Demo, D. H., \& Parker, K. D. (1987). Academic achievement and self-esteem among black and white college students. The Journal of Social Psychology, 127, 345-355.

[12] Ehrman, M. E., \& Oxford, R. (1990). Adult language learning styles and strategies in an intensive training setting. Modern Language Journal, 74, 11-27.

[13] Ellis,R. (2004). Individual Differences in Second Language Learning. In A. Davies \& C. Elder (Eds), The Handbook of Applied Linguistics (pp. 525-551). Oxford: Oxford University Press.

[14] Erton,I. (2010). Relationship between personality types and success in foreign language achievement. Journal of Education, 38,115-126.

[15] Eysenck, S. B. G., \& Eysenck, H. J. (1964b). An improved short questionnaire for the measurement of extraversion and neuroticism. Life Sciences, 3, 1103-1109.

[16] Farely, F .,\& Truog, A.(1970). Individual differences in reading comprehension. Journal of Reading Behavior, 3, 29-35.

[17] Frankburger, P. (1991). An annotated bibliography of the literature dealing with the effects of student attitude and teacher behaviour on writing apprehension and compositions quality. (ERIC Document Reproduction Service No. ED 333482)

[18] Gardner, R. C. (1972). The relationship of self esteem and variables associated with reading for fourth grade pima Indian children. Unpublished doctoral dissertation, The University of Arizona, USA.

[19] Gheedj,z.(2010). The relationship between personality types, test anxiety and self-esteem with regards to academic achievement. http://www.opppapers.com(accessed 16/09/2011).

[20] Grandin, T. (2002). Asperger's and self-esteem: Insight and hope through famous role models. Arlington, TE: Future Horizons.

[21] Grobe,W., \& Stoller, L. (2001). " Reading for academic purpose: guidelines for the ESL/EFL teacher," In M. Celce-Murcia (Ed.), Teaching English as a Second or Foreign Language(pp187-203). Boston: Heinle and Heinle.

[22] Grodnick, J. R. (1996). Self-esteem and writing achievement. Unpublished master's thesis, New Jersey, USA.

[23] Hajimohammadi, R. (2011). Impact of self correction on extrovert and introvert students in EFL writing progress. English Language Teaching, 4, 3-5.

[24] Hassan, B. (1992). Foreign language self-esteem and the oral communicative ability of university students. Mansoura Faculty of Education Journal, 19, 1-19.

[25] Hassan, B. (2001).The relationship of writing apprehension and self esteem to the writing quality and quantity of EFL university students. (ERIC Document Reproduction Service No. ED 459671)

[26] Hayati, A., \& Ostadian, M. (2008). The relationship between self-esteem and listening comprehension of EFL students. Glossa, $3,300-312$ 
[27] Heyde, A. (1979). The relationship between self esteem and the oral production of second language. Unpublished doctoral dissertation, The University of Michigan, USA.

[28] Hosseini, M ., \& Kafipour, R. (2011). The relationship among extraversion tendency, vocabulary learning strategies, and reading comprehension of EFL undergraduates in Kerman province. Studies in Literature and Language, 3, 104-110.

[29] Hutchinson, M. A. (1972). A study of the relationship of intermediate-grade children's self-esteem and their attitude toward reading. ERIC Document Reproduction Service No. ED06361

[30] Marefat, F. (2006). Students' writing and their personality type. Reading matrix, 6, 33-38.

[31] Murk, C. (1999). Self-esteem Research, Theory and Practice. New York: Springer

[32] Naiman, N., Fröhlich, M., Stern, H., and Todesco, A. (1978). The Good Language Learner. Research in Education Series No. 7, Toronto: The Ontario Institute for Studies in Education

[33] Oya, T. (2004). The influence of personality and anxiety on the oral performance of Japanese speakers of English. Applied cognitive psychology, 18,841-842.

[34] Pajares, F., \& Johnson, M. (1993). Confidence and competence in writing: The role of self-efficacy, outcomes expectancy and apprehension. Paper presented at the annual meeting of The American Educational Research Association, Atlanta, USA. (ERIC Document Reproduction Service No. ED358474).

[35] Phillips, D. (2001). Longman complete course for the TOEFL test. New York: Pearson education.

[36] Qomadrin, A. (2010). Correlation between extraversion personality and writing skill. Unpublished doctoral dissertation, Diponegoro University, Semarang

[37] R. Day., \& J. S. Park. 'Developing reading comprehension,". http://nflrc.hawaii.edu/rfl/ PastIssues/author.html (accessed $11 / 07 / 2005)$.

[38] Reasoner, R. (2004a). The true meaning of self-esteem. National Association for Self-esteem (NASE). http://www.self-esteemnase.org/(accessed 21/01/2005).

[39] Richardson, C. (2003). The relationship between self-esteem and reading. (ERIC Document Reproduction Service No. ED474965).

[40] Riding, R., \& Cowley, J. (2011). Extraversion and sex differences in reading performance in eight-year-old children. British Journal of Educational Psychology, 56, 88-94.

[41] Rosenberg, M. (1979). Conceiving the Self. New York: Basic Books.

[42] Schmeck, R.R., ed. (1988). Learning Strategies and Learning Styles. New York: Plenum Press

[43] Shumin, K. (1997). Factors to consider: Developing adult EFL students speaking abilities. Forum, 35(3), 8-19.

[44] Stevick, E. (1990). Humanism in Language Teaching (3rd ed.). Oxford, UK: Oxford University Press.

[45] Stout, M. (2001). The feel-good curriculum: The dumbing down of America's kids in the name of self-esteem. USA: Da Capo Press.

[46] Suter, R. (1976). Predictors of pronunciation accuracy in second language learning. Language Learning, 26, 233-253.

[47] Swartz, D. (1972). The relationship of self-esteem to reading performance. Unpublished doctoral dissertation, University of Northern Colorado, USA.

[48] Sweet, A., \& Burbach, H. (1977). Self-esteem and reading achievement. Paper presented at the annual meeting of The American Educational Research Association, New York, USA. (ERIC Document Reproduction Service No. ED137756)

[49] Timothy J. O., Sheldon, S., \& Norman, G. (2001). Extending self-esteem theory and research (2nd ed.). Cambridge: Cambridge University Press.

[50] Truitt, S. N. (1995). Anxiety and beliefs about language learning: A study of Korean university students learning English. Unpublished doctoral dissertation, The University of Texas, Austin, USA.

[51] Vivian, M. (2006). Personality types, motivational factors, and reading performance of high school students. Faculty Research Journal, 27, 35-47.

[52] Weintraub, S. (1992). Annual summary of investigations relating to reading. Delaware: international reading association.

[53] Wilz, B. (2000). Relationship between personality type and Grade Point Average of technical college students. Unpublished MA thesis, University of Wisconsin-Stout.

[54] Xue Za, Y. (2006). The relationship between test anxiety and personality, self-esteem in grade one senior high students. Zhonghua Yu Fang Yi Xue Za Zhi, 5 ,44-50.

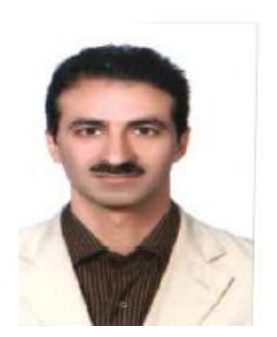

Mohammad Sadeq Bagheri was born in Shiraz Iran, in 1963. He finished his MA in 1995 and obtained his $\mathrm{PhD}$ in Teaching English as a Foreign Language (TEFL) in Shiraz University in 2006.

$\mathrm{He}$ is currently an assistant professor teaching M.A. and $\mathrm{PhD}$ courses and working as the dean at the humanities faculty of Islamic Azad University, Shiraz Branch.

His main areas of interest are e-learning, motivation, learning strategies and international exams. 


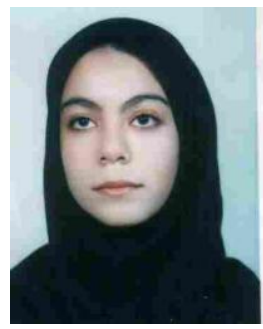

Mehrnaz Faghih was born in Shiraz, Iran in 1987. She received her M.A. degree in English language teaching from Shiraz Azad University, Iran in 2012, and also she received her B.A. degree in English language teaching from Shiraz Azad University, Iran in 2008.

She has been teaching general English in private language institutes in Shiraz from 2006 to date.

Her research interests include affective factors in language learning. 